\title{
Balneola vulgaris gen. nov., sp. nov., a member of the phylum Bacteroidetes from the north-western Mediterranean Sea
}

\author{
Laurent Urios, ${ }^{1}$ Hélène Agogué, ${ }^{1}$ Françoise Lesongeur, ${ }^{2}$ \\ Erko Stackebrandt ${ }^{3}$ and Philippe Lebaron ${ }^{1}$
}

Correspondence Philippe Lebaron lebaron@obs-banyuls.fr

\author{
'Observatoire Océanologique, Laboratoire d'Océanographie Biologique de Banyuls, Université \\ Pierre et Marie Curie (Paris VI), Institut National des Sciences de I'Univers (INSU), CNRS \\ UMR 7621, BP44, 66651 Banyuls-sur-Mer Cedex, France \\ ${ }^{2}$ Laboratoire de Microbiologie des Environnements Extrêmes, UMR 6197, IFREMER, Centre de \\ Brest, BP70, 29280 Plouzané, France \\ ${ }^{3} \mathrm{DSMZ}$ - Deutsche Sammlung von Mikroorganismen und Zellkulturen GmbH, Mascheroder \\ Weg 1b, 38124 Braunschweig, Germany
}

\begin{abstract}
A novel aerobic, Gram-negative bacterium, named $13 \mathrm{XX} / \mathrm{A01} / 164^{\top}$, was isolated from surface waters in the coastal north-western Mediterranean Sea. Cells were motile, straight rods, $2.5 \mu \mathrm{m}$ long and $0.2 \mu \mathrm{m}$ wide, and formed orange colonies on marine agar medium. The $\mathrm{G}+\mathrm{C}$ content of the genomic DNA of strain $13 \mathrm{IX} / \mathrm{A01} / 164^{\top}$ was $42 \mathrm{~mol} \%$. Phylogenetic analysis of the $16 \mathrm{~S}$ rRNA gene sequence placed the strain in the phylum Bacteroidetes within the family Crenotrichaceae. On the basis of 16S rRNA gene sequence comparison and physiological and biochemical characteristics, this isolate represents a novel species of a new genus, for which the name Balneola vulgaris gen. nov., sp. nov. is proposed. The type strain of Balneola vulgaris is $13 \mathrm{IX} / \mathrm{A01} / 164^{\top}$ $\left(=\operatorname{DSM} 17893^{\top}=\right.$ CIP $109092^{\top}=$ OOB $\left.256^{\top}\right)$.
\end{abstract}

Micro-organisms were the first form of life on Earth and they are found everywhere in nature, including extreme environments like hot springs and salt marshes. Samples collected in these hostile environments have revealed a wide range of micro-organisms that have adapted not only to survive, but also to reproduce under extreme conditions. Many of these organisms belong to the Archaea and they sometimes exhibit very interesting properties that have potential in biotechnological applications. For this reason, there is an increasing interest in exploring microbial diversity in these ecosystems (Demirjian et al., 2001). However, although the majority of thermophilic and extremely halophilic micro-organisms belong to the Archaea, members of the Bacteria with similar characteristics and properties have been isolated. For example, the orders Thermales (Rainey \& da Costa, 2001) and Thermotogales (Huber \& Stetter, 1992) encompass 13 genera of thermophilic strains and the genera Halorhodospira (Imhoff \& Süling, 1996) and Salinibacter (Antón et al., 2002) are composed of extremely halophilic species. Some recently described genera, such as

The GenBank/EMBL/DDBJ accession number for the 16S rRNA gene sequence of strain $13 \mathrm{IX} / \mathrm{A} 01 / 164^{\top}$ is AY576749.

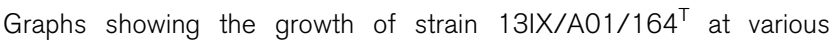
temperatures, salt concentrations and $\mathrm{pH}$ values are available as supplementary material in IJSEM Online.
Rhodothermus and Thermonema, belong to the family Crenotrichaceae within the Bacteroidetes. This family is remarkable as all its members described to date exhibit characteristics that are regarded as extremophilic. Species of the genera Rhodothermus (Alfredsson et al., 1988; Sako et al., 1996) and Thermonema (Hudson et al., 1989; Tenreiro et al., 1997) are thermophilic and have optimal growth temperatures between 60 and $80^{\circ} \mathrm{C}$. Isolates of the genus Salinibacter are extremely halophilic and require at least $150 \mathrm{~g}$ salt $\mathrm{l}^{-1}$ for growth. In this paper, a novel strain of the family Crenotrichaceae, isolated from the north-western Mediterranean Sea, is described; this strain represents the first member of this family that does not exhibit the extreme characteristics that are found in other members of the family.

Samples were collected in September 2001 in the bay of Banyuls-sur-Mer $\left(42^{\circ} 29^{\prime} \mathrm{N} 3^{\circ} 08^{\prime} \mathrm{E}\right)$ by submerging a sterile bottle and opening it at a depth of $0.5 \mathrm{~m}$ (Agogué et al., 2004). Subsamples were spread on marine agar plates (MA 2216; Difco) and incubated at $25^{\circ} \mathrm{C}$ for 2 weeks. Colonies were picked and purified after at least three subcultures. Among these colonies, an isolate that formed orangecoloured colonies was obtained and referenced as strain 13IX/A01/164 ${ }^{\mathrm{T}}$ (Agogué et al., 2005).

Microscopic observations (Olympus AX70) indicated that cells of strain $13 \mathrm{IX} / \mathrm{A} 01 / 164^{\mathrm{T}}$ were motile rods, 
approximately $2 \cdot 5 \pm 0 \cdot 4 \mu \mathrm{m}$ long and $0 \cdot 2 \pm 0 \cdot 06 \mu \mathrm{m}$ wide. No gliding motility was observed. Cells were negatively stained for transmission electron microscopy (Raguénès et al., 1997). A polar flagellum was observed (Fig. 1). The Ryu $\mathrm{KOH}$ reaction (Powers, 1995) led to immediate cell lysis that was confirmed by phase-contrast microscopy (Olympus AX70). This positive reaction indicated that cells were Gram-negative.

The strain was grown in marine broth medium (MB 2216; Difco). Marine broth medium with a range of salinities was prepared according to the composition provided by the manufacturer with the appropriate $\mathrm{NaCl}$ concentration. To study growth at a range of $\mathrm{pH}$ values, MES, PIPES, AMPSO or MOPS (Sigma) was added to marine broth medium to reach the required $\mathrm{pH}$. Cultures were incubated at $30^{\circ} \mathrm{C}$ under aerobic conditions. Methods for the determination of growth parameters were as reported by Wery et al. (2001b). Growth was observed at 10$40{ }^{\circ} \mathrm{C}$, with optimum growth at $30^{\circ} \mathrm{C}$ (see Supplementary Fig. S1a available in IJSEM Online). The strain grew at $\mathrm{NaCl}$ concentrations of $0-70 \mathrm{~g} \mathrm{l}^{-1}$; an optimum concentration for growth could be defined at $10 \mathrm{~g} \mathrm{l}^{-1}$, but growth rates were quite similar at 5 and $20-40 \mathrm{~g} \mathrm{l}^{-1}$ (Supplementary Fig. S1b). Growth occurred at $\mathrm{pH} 5 \cdot 0$ $10 \cdot 0$, with a clear optimum at $\mathrm{pH} 8 \cdot 0$. A linear increase

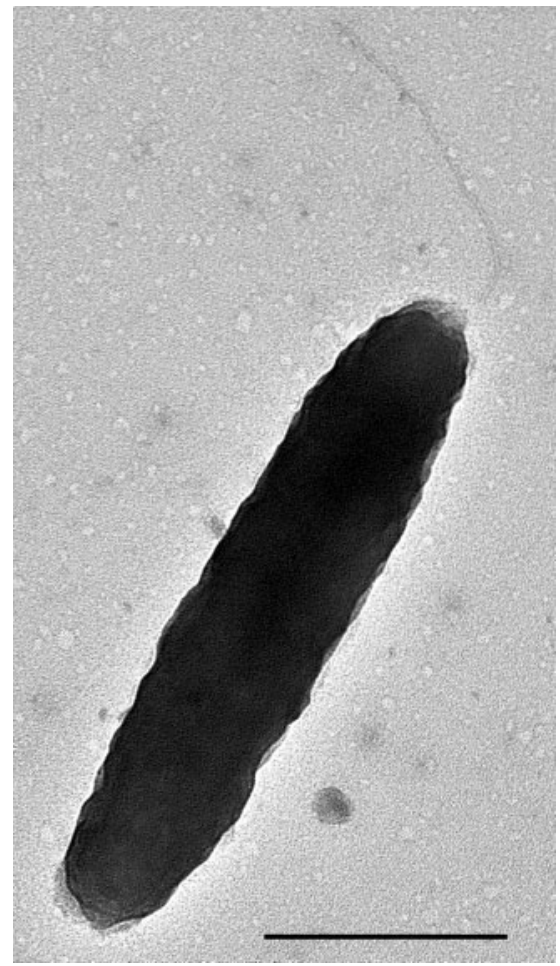

Fig. 1. Electron micrograph of a negatively stained cell of strain 13 IX/A01/164 $4^{\top}$ harvested during the exponential phase. A single polar flagellum is shown. Bar, $1 \mu \mathrm{m}$. in the growth rate was observed from $\mathrm{pH} 5 \cdot 0$ to $8 \cdot 0$; at $\mathrm{pH} 9 \cdot 0$, growth decreased dramatically to $60 \%$ of the value obtained at $\mathrm{pH} 8 \cdot 0$ (Supplementary Fig. S1c). The shortest generation time observed was $23 \mathrm{~min}$. The ability to use different substrates was investigated with Biolog GN2 MicroPlates (De Groote et al., 1999) according to the manufacturer's instructions except for the incubation time (measurements were performed every hour for $24 \mathrm{~h}$ ). Positive reactions are indicated in Table 1. Weak positive reactions were observed for cellobiose, lactose and $\gamma$ hydroxybutyrate.

Enzyme activities were investigated using the API ZYM system (bioMérieux) according to the manufacturer's instructions. Alkaline phosphatase, leucine arylaminidase, valine arylaminidase, trypsin, chymotrypsin and acid phosphatase exhibited positive reactions. Colour reactions for esterase (C8) and cystine arylamidase were weak. Catalase and oxidase tests were performed; the strain was found to be catalase-positive and oxidase-negative. The presence of flexirubin pigments was investigated according to McCammon \& Bowman (2000); a negative reaction was observed.

Fatty acid methyl esters were extracted and prepared by the standard protocol of the Microbial Identification System (MIDI; Microbial ID) using cells grown in MB. As cells did not grow on the medium recommended by the MIDI system (trypticase soy broth), the fatty acids obtained could not be compared directly to those of the MIDI database. Extracts were analysed using a Hewlett Packard model HP6890A GC equipped with an FID as described previously (Kämpfer \& Kroppenstedt, 1996). The fatty acid composition of strain 13IX/A01/164 ${ }^{\mathrm{T}}$ was as follows: $15: 0$ iso $(23 \cdot 5 \%), 15: 0$ iso $2-\mathrm{OH}(11 \cdot 3 \%), 17: 1 \omega 8 c(11 \%)$, $15: 0(10 \cdot 7 \%), 15: 1 \omega 6 c(10 \cdot 6 \%), 13: 0$ iso $(6 \cdot 5 \%)$, $17: 1 \omega 9 c$ iso $(6 \cdot 5 \%), 15: 0$ anteiso $(4 \cdot 1 \%), 17: 1 \omega 6 c$ $(3 \cdot 2 \%), 14: 0$ iso $(2 \cdot 3 \%), 16: 0$ iso $(2 \cdot 3 \%), 17: 0$ iso $(1 \cdot 5 \%), 16: 0(1 \cdot 4 \%), 17: 0(1 \%), 15: 1 \omega 8 c(1 \%)$, and $16: 1 \omega 5 c(1 \%)$. Although fatty acid data are missing for species of Salinibacter, those of Rhodothermus (Silva et al., 2000) have significantly different compositions, with major amounts ( $>20 \%$ each) of 17:0 anteiso, 15:0 anteiso and $17: 0$ iso.

Genomic DNA was extracted as described by Wery et al. (2001a). The $\mathrm{G}+\mathrm{C}$ content was determined by thermal denaturation using the method of Marmur \& Doty (1962) and conditions reported by Raguénès et al. (1997). The $\mathrm{G}+\mathrm{C}$ content of the genomic DNA of strain 13IX/A01/164 was $41 \cdot 8 \pm 1 \cdot 1 \mathrm{~mol} \%$. The $16 \mathrm{~S}$ rRNA gene was amplified and sequenced as described by Agogué et al. (2005). The sequence was compared to those available in GenBank using BLAST (Altschul et al., 1997). Alignments and similarities were obtained by the CLUSTAL X method. The phylogenetic reconstruction was produced using PHYLO_WIN (Galtier et al., 1996) with the Jukes-Cantor correction for determination of the distance matrix, followed by neighbour joining (Saitou \& Nei, 1987) for determination of the 
Table 1. Comparison of some characteristics of strain $13 I X / A 01 / 164^{\top}$ and closely related species

+ , Positive; - , negative; $(+)$, weakly positive; ND, no data available.

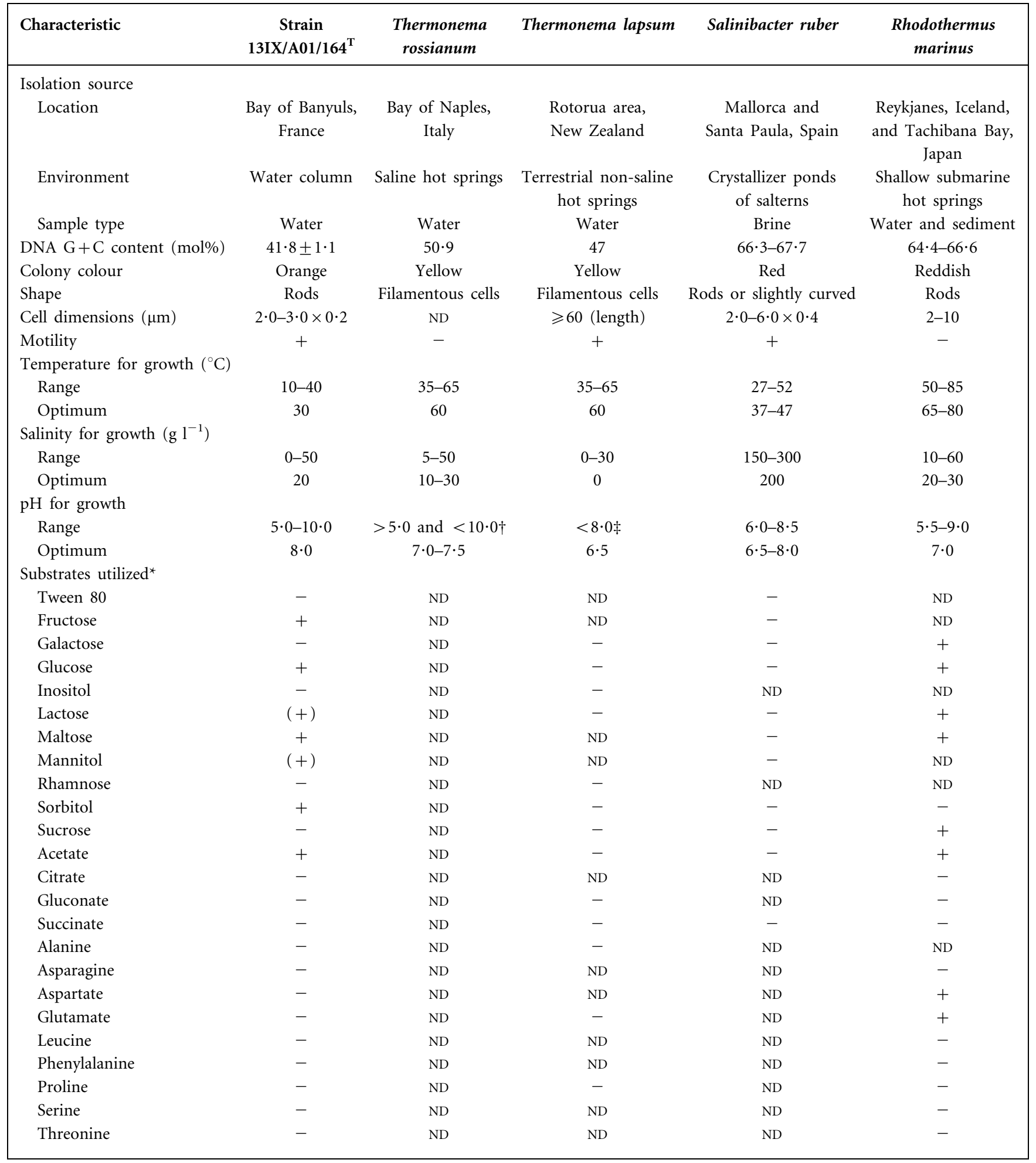

${ }^{\star}$ Results of substrate utilization tests were not given in enough detail in the description of $T$. rossianum.

$\dagger$ No growth was observed at $\mathrm{pH} 5 \cdot 0$ or $\mathrm{pH} 10 \cdot 0$.

$\ddagger$ No growth was observed at $\mathrm{pH} 8 \cdot 0$; the lower $\mathrm{pH}$ limit for growth is unknown. 
best phylogenetic tree. Maximum-likelihood methods (Felsenstein, 1981) were also employed for phylogenetic analysis. Bootstrap values were determined according to Felsenstein (1985). Strain 13IX/A01/164 ${ }^{\mathrm{T}}$ was phylogenetically affiliated to the family Crenotrichaceae within the phylum Bacteroidetes (Fig. 2) and was most closely related to Rhodothermus marinus NR-32 ${ }^{\mathrm{T}}$ (16S rRNA gene sequence similarity of $87 \%$ ). Strain 13 IX/A01/164 ${ }^{\mathrm{T}}$ was also closely related to strains of Salinibacter ruber, Thermonema rossianum and Thermonema lapsum.

Some characteristics of strain 13IX/A01/164 ${ }^{\mathrm{T}}$ were quite similar to those of its nearest relatives, including colony pigmentation, salinity growth range (with the exception Salinibacter ruber, which is extremely halophilic) and $\mathrm{pH}$ growth range (with a slightly higher optimum) (Table 1). Nevertheless, strain 13IX/A01/164 ${ }^{\mathrm{T}}$ exhibited no extreme characteristics, it is neither thermophilic nor halophilic, and the environment from which it was isolated clearly differed from those where the most closely related species were found. No filamentous cells, such as those observed with Thermonema strains, were observed. The DNA $G+C$ content of strain 13 IX/A01/164 ${ }^{\mathrm{T}}$ was significantly lower (by 5-24 mol\%) than those of related species.

Based on phenotypic and genotypic differences between strain 13IX/A01/164 ${ }^{\mathrm{T}}$ and its nearest relatives, it is proposed

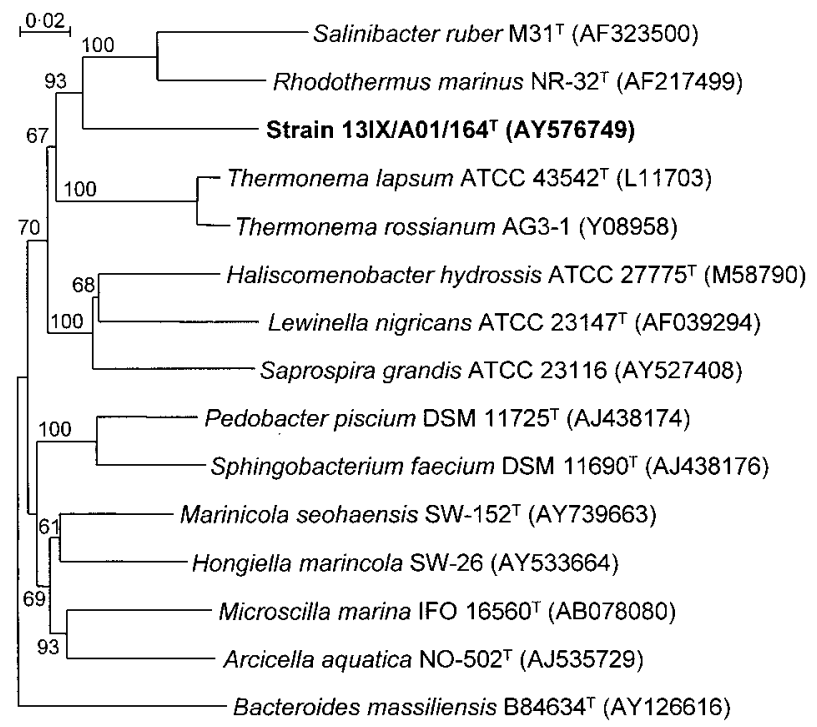

Fig. 2. Phylogenetic tree based on $16 \mathrm{~S}$ rRNA gene sequences showing the position of strain $13 \mathrm{IX} / \mathrm{A01} / 164^{\top}$. Bacteroides massiliensis $B 84634^{\top}$ was used as an outgroup. Accession numbers are indicated in parentheses. The tree corresponds to an unrooted tree obtained by the neighbour-joining algorithm (Kimura corrections). Bootstrap percentages from 500 replicates are displayed on their relative branches. that strain $13 \mathrm{IX} / \mathrm{A} 01 / 164^{\mathrm{T}}$ should be assigned as a representative of a novel species in a new genus belonging to the Crenotrichaceae. Because of the geographical origin of strain 13IX/A01/164 ${ }^{\mathrm{T}}$ and its lack of original characteristics compared with the extremophilic behaviour of the most closely related species, the name Balneola vulgaris gen. nov., sp. nov. is proposed.

\section{Description of Balneola gen. nov.}

Balneola (Bal.ne'o.la. M.L. fem. n. Balneola the ancient name of Banyuls, referring to the area of isolation of the first characterized strain).

Aerobic, motile, Gram-negative rod growing optimally at $30{ }^{\circ} \mathrm{C}$ and $\mathrm{pH} 8 \cdot 0$. Catalase-positive and oxidase-negative. The major fatty acids are $15: 0$ iso $(23 \cdot 5 \%), 15: 0$ iso $2-\mathrm{OH}$ $(11 \cdot 3 \%), \quad 17: 1 \omega 8 c \quad(11 \%), \quad 15: 0 \quad(10 \cdot 7 \%), \quad 15: 1 \omega 6 c$ $(10 \cdot 6 \%), 13: 0$ iso $(6 \cdot 5 \%)$ and $17: 1 \omega 9 c$ iso $(6 \cdot 5 \%)$. Phylogenetically affiliated with the phylum Bacteroidetes within the family Crenotrichaceae. The type species is Balneola vulgaris.

\section{Description of Balneola vulgaris sp. nov.}

Balneola vulgaris (vul.ga'ris. L. fem. adj. vulgaris common, referring to the lack of specific characteristics).

Forms orange colonies on MA medium. Grows at 10 $40{ }^{\circ} \mathrm{C}$ (optimum $30{ }^{\circ} \mathrm{C}$ ), $\mathrm{pH} 5 \cdot 0-10 \cdot 0$ (optimum $\mathrm{pH} 8 \cdot 0$ ) and a salinity range of $0-50 \mathrm{~g} \mathrm{l}^{-1}$ (optimum $20 \mathrm{~g} \mathrm{l}^{-1}$ ). Positive reactions with Biolog GN2 plates are obtained for $\mathrm{N}$-acetylgalactosamine, adonitol, arabinose, arabitol, erythritol, fructose, fucose, glucose, lactulose, maltose, methyl glucoside, sorbitol, acetate, hydroxyphenylacetate and propionate. Positive reactions with the API ZYM system are obtained for alkaline phosphatase, leucine arylaminidase, valine arylaminidase, trypsin, chymotrypsin and acid phosphatase. Other characteristics are given in Table 1.

The type strain is $13 \mathrm{IX} / \mathrm{A} 01 / 164^{\mathrm{T}}\left(=\mathrm{DSM} 17893^{\mathrm{T}}=\mathrm{CIP}\right.$ $109092^{\mathrm{T}}=\mathrm{OOB} 256^{\mathrm{T}}$ ), isolated from a water column in the bay of Banyuls-sur-Mer $\left(42^{\circ} 29^{\prime} \mathrm{N} 3^{\circ} 08^{\prime} \mathrm{E}\right)$. The DNA $\mathrm{G}+\mathrm{C}$ content of strain $13 \mathrm{IX} / \mathrm{A} 01 / 164^{\mathrm{T}}$ is $42 \mathrm{~mol} \%$.

\section{Acknowledgements}

We thank Laurent Intertaglia from the OOB and Magali Cros for their technical assistance. This work was partly funded by the AIRWIN project 'Structure and role of biological communities involved in the transport and transformation of persistent pollutants at the marine AIR-Water INterface' (contract EVK3-CT2000-00030). The project was also carried out in the frame of the MarBEF Network of Excellence 'Marine Biodiversity and Ecosystem Functioning' which is funded in the Community's Sixth Framework Programme (contract no. GOCECT-2003-505446). This publication is contribution number MPS06027 of MarBEF. It was also partly funded by the French program 'Bio-diversité et Changement Global - project: development of a coastal microbial observatory' from the Institut Français de la Biodiversité. 


\section{References}

Agogué, H., Casamayor, E. O., Joux, F. \& 8 other authors (2004). Comparison of samplers for the biological characterization of the sea surface microlayer. Limnol Oceanogr Methods 2, 213-225.

Agogué, H., Casamayor, E. O., Bourrain, M., Obernosterer, I., Joux, F., Herndl, G. J. \& Lebaron, P. (2005). A survey on bacteria inhabiting the sea surface microlayer of coastal ecosystems. FEMS Microbiol Ecol 54, 269-280.

Alfredsson, G. A., Kristjansson, J. K., Hjörleifsdottir, S. \& Stetter, K. O. (1988). Rhodothermus marinus gen. nov., a thermophilic, halophilic bacterium from submarine hot springs in Iceland. J Gen Microbiol 134, 299-306.

Altschul, S. F., Madden, T. L., Schaffer, A. A., Zhang, J., Zhang, Z., Miller, W. \& Lipman, D. J. (1997). Gapped BLAST and PSI-BLAST: a new generation of protein database search programs. Nucleic Acids Res 25, 3389-3402.

Antón, J., Oren, A., Benlloch, S., Rodríguez-Valera, F., Amann, R. \& Rosselló-Mora, R. (2002). Salinibacter ruber gen. nov., sp. nov., a novel, extremely halophilic member of the Bacteria from saltern crystallizer ponds. Int J Syst Evol Microbiol 52, 485-491.

De Groote, D., van Doorn, L. J., Ducatelle, R., Verschuuren, A., Tilmant, K., Quint, W. G. V., Haesebrouck, F. \& Vandamme, P. (1999). Phylogenetic characterization of 'Candidatus Helicobacter bovis', a new gastric helicobacter in cattle. Int J Syst Bacteriol 49, $1707-1715$.

Demirjian, D. C., Moris-Varas, F. \& Cassidy, C. S. (2001). Enzymes from extremophiles. Curr Opin Chem Biol 5, 144-151.

Felsenstein, J. (1981). Evolutionary trees from DNA sequences: a maximum likelihood approach. J Mol Evol 17, 368-376.

Felsenstein, J. (1985). Confidence limits on phylogenies: an approach using the bootstrap. Evolution 39, 783-791.

Galtier, N., Gouy, M. \& Gautier, C. (1996). SEAVIEW and PHYLO_WIN: two graphic tools for sequence alignment and molecular phylogeny. Comput Appl Biosci 12, 543-548.

Huber, R. \& Stetter, K. O. (1992). The order Thermotogales. In The Prokaryotes, 2nd edn, vol. IV, pp. 3809-3815. Edited by A. Balows, H. G. Trüper, M. Dworkin, W. Harder \& K.-H. Schleifer. New York: Springer.

Hudson, J. A., Schofield, K. M., Morgan, H. W. \& Daniel, R. M. (1989). Thermonema lapsum gen. nov., sp. nov., a thermophilic gliding bacterium. Int J Syst Bacteriol 39, 485-487.

Imhoff, J. F. \& Süling, J. (1996). The phylogenetic relationship among Ectothiorhodospiraceae: a reevaluation of their taxonomy on the basis of 16S rDNA analyses. Arch Microbiol 165, 106-113.

Kämpfer, P. \& Kroppenstedt, R. M. (1996). Numerical analysis of fatty acid patterns of coryneform bacteria and related taxa. Can J Microbiol 42, 989-1005.
Marmur, J. \& Doty, P. (1962). Determination of the base composition of deoxyribonucleic acid from its thermal denaturation temperature. J Mol Biol 4, 109-118.

McCammon, S. A. \& Bowman, J. P. (2000). Taxonomy of Antarctic Flavobacterium species: description of Flavobacterium gillisiae sp. nov., Flavobacterium tegetincola sp. nov. and Flavobacterium xanthum sp. nov., nom. rev., and reclassification of [Flavobacterium] salegens as Salegentibacter salegens gen. nov., comb. nov. Int J Syst Evol Microbiol 50, 1055-1063.

Powers, E. (1995). Efficacy of the Ryu nonstaining $\mathrm{KOH}$ technique for rapidly determining Gram reactions of food-borne and waterborne bacteria and yeasts. Appl Environ Microbiol 61, 3756-3758.

Raguénès, G., Christen, R., Guézennec, J., Pignet, P. \& Barbier, G. (1997). Vibrio diabolicus sp. nov., a new polysaccharide-secreting organism isolated from a deep-sea hydrothermal vent polychaete annelid, Alvinella pompejana. Int J Syst Bacteriol 47, 989-995.

Rainey, F. A. \& da Costa, M. S. (2001). Order II. Thermales ord. nov. In Bergey's Manual of Systematic Bacteriology, 2nd edn, vol. 1 (The Archaea and the Deeply Branching and Phototrophic Bacteria), p. 403. Edited by D. R. Boone, R. W. Castenholz \& G. M. Garrity. New York: Springer-Verlag.

Saitou, N. \& Nei, M. (1987). The neighbor-joining method: a new method for reconstructing phylogenetic trees. Mol Biol Evol 4, 406-425.

Sako, Y., Takai, K., Ishida, Y., Uchida, A. \& Katayama, Y. (1996). Rhodothermus obamensis sp. nov., a modern lineage of extremely thermophilic marine bacteria. Int J Syst Bacteriol 46, 1099-1104.

Silva, Z., Horta, C., da Costa, M. S., Chung, A. P. \& Rainey, F. A. (2000). Polyphasic evidence for the reclassification of Rhodothermus obamensis Sako et al. 1996 as a member of the species Rhodothermus marinus Alfredsson et al. 1988. Int J Syst Evol Microbiol 50, 1457-1461.

Tenreiro, S., Nobre, M. F., Rainey, F. A., Miguel, C. \& da Costa, M. S. (1997). Thermonema rossianum sp. nov., a new thermophilic and slightly halophilic species from saline hot spring in Naples, Italy. Int J Syst Bacteriol 47, 122-126.

Wery, N., Lesongeur, F., Pignet, P., Derennes, V., Cambon-Bonavita, M. A., Godfroy, A. \& Barbier, G. (2001a). Marinitoga camini gen. nov., sp. nov., a rod-shaped bacterium belonging to the order Thermotogales, isolated from a deep-sea hydrothermal vent. Int J Syst Evol Microbiol 51, 495-504.

Wery, N., Moricet, J. M., Cueff, V., Jean, J., Pignet, P., Lesongeur, F., Cambon-Bonavita, M. A. \& Barbier, G. (2001b). Caloranaerobacter azorensis gen. nov., sp. nov., an anaerobic thermophilic bacterium isolated from a deep-sea hydrothermal vent. Int J Syst Evol Microbiol 51, 1789-1796. 